\title{
TRANSMEDIALIZING THE FANTASTIC, A USER-BASED APPROACH
}

\author{
JAN BAETENS \\ Katholieke Universiteit Leuven, Nar-Trans2 \\ jan.baetens@kuleuven.be \\ DOMINGO SÁNCHEZ-MESA \\ Universidad de Granada, Nar-Trans2 \\ elquellegatarde@gmail.com
}

Recibido: 03-08-2020

Aceptado: 04-10-2020

(c) (1)

\section{ABSTRACT}

This article deals with some methodological issues regarding the relationship between medium (more specifically the question of transmediality) and use (more specifically the issue of interactivity) in the field of the fantastic. More specifically, it discusses some fundamental hypotheses on the way the interactive dimension of transmedial adaptations can either increase or diminish the fantastic effect. A special emphasis will be put on issues of time and narrative, on the one hand, and context and medium traditions, on the other hand.

KEYWORDS: Intensity, fantastic, narrative, participation, transmediality.

\section{TRANSMEDIALIZANDO LO FANTÁSTICO: UNA APROXIMACIÓN BASADA EN EL USUARIO}

\section{RESUMEN}

Este artículo aborda algunas cuestiones metodológicas concernientes a la relación entre medio (más en concreto, el asunto de la transmedialidad) y uso (más en concreto, el tema de la interactividad) en el área de lo fantástico. En particular, reflexiona sobre 
ciertas hipótesis fundamentales en torno a la manera en la que la faceta interactiva de las adaptaciones transmediales puede incrementar o disminuir el efecto fantástico. Se prestará especial atención a las cuestiones de tiempo y narración, por una parte, y de contexto y tradiciones mediáticas, por otra.

Palabras ClaVE: Intensidad, fantástico, narración, participación, transmedialidad.

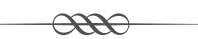

Fantastic, transmediality, interactivity: the gathering of these three notions and fields, each of them inextricably linked with historical practices and involving a wide range of theoretical underpinnings and choices, is both a challenge and an opportunity. On the one hand, the very complexity of their connections bears the risk of focusing on a partial view of their relationships, that is of examining binary relationships (between just fantastic and transmediality or just transmediality and interactivity or just interactivity and fantastic) that are definitely interesting and rewarding but overlook the global picture of the links between all of the three notions involved. On the other hand, it is also opening the box of Pandora of the very definition of these three concepts, which remains open to debate, to put it mildly. Before entering the heart of the discussion in order to suggest a possible way of analyzing the connections between fantastic, transmediality and interactivity, it is therefore imperative to plainly expose what we mean by each of these terms, both for the sake of clarity as for the multiple implications of these issues on the way in which we will build our argumentation.

WHAT DO WE SAY WHEN WE USE THE WORDS «FANTASTIC», «TRANSMEDIALITY», AND «INTERACTIVITY»?

The fantastic itself, to start with, will be defined here in a very traditional way, as the encounter of and the hesitation between the natural and the supernatural, resulting in an impression of uncanniness (Todorov, 1970) or, to put it in other words, it is the consequence of the confrontation between the real and the impossible (Roas, 2001, 2011). We will not explore more unconventional definitions, such as the one defended by Charles Grivel, also an in- 
fluential figure in French intermediality studies (Letourneux and Migozzi, 2018), in his book Fantastique-Fiction (Grivel, 1992), since our main focus will be on questions of mediality, more precisely on the impact of interactive medium issues on our experience of the fantastic. The fantastic in itself is not directly medium-bound: it is a general category that appears across media; moreover, it does not seem particularly resistant to all kinds of remediation. This does not mean however that medium is not a relevant dimension: there are media that seem to do a better job than others as far as the fantastic is concerned, while not all types of remediation, regardless of the intrinsic merits of a given adaptation, are necessarily successful.

Although it would be dangerous to generalize, one intuitively feels that specific uses of a given medium, whatever it is, are capable of generating stronger fantastic effects than other uses of the same medium. The major aim of this article is therefore to suggest that particular shifts in medium structure should be seen as a key aspect of the production of the fantastic. From this point of view, changes having to do with transmediality and interactivity, two notions which we will define in the following paragraphs, can be either «successful» (if they prove to increase the effect of the encounter between the real and the unreal) or «unsuccessful» (if they fail to do so). Once again, we carefully try to avoid any generalization. Just as it is impossible to argue that medium A better fits the fantastic than medium B, it is impossible to claim that this or that type of change in transmediality and / or interactivity is better suited to produce fantastic effects than other types. However, what should be clear is that the use of transmedial and interactive mechanisms can have powerful consequences for the experience of the fantastic.

The notion of transmediality, as repeatedly defended in joint articles by the authors (see Baetens \& Sánchez-Mesa, 2017 and 2019), cannot be separated from the notion of intermediality. If one accepts the idea that all media are intermedial (Mitchell, 2005), transmediality can be defined as the «dynamic» version of this fundamental observation of any medium's internal complexity: all media are intermedial and each of them can be transmedialized, that is converted into another medium. In other words: there is in principle no limit to the mechanism of transmedialization or medium change, provided one stops thinking that it is possible to transmedialize one medium into another without changes. Transmediality itself can take two major forms (Jenkins, 2006): «snowball» transmediality, which relies on the successive or sequential transformation of a given medium in one or more other media (a novel becoming first a film, then a novel, eventually a videogame, for instance); «trans- 
media storytelling», which relies on the simultaneous realization of a given content (in this case a narrative content) into different media (a franchised story world being released at the same time as novel, film, comic, and videogame, to take a common example).

Three further remarks may be useful here. First, it is often argued that transmediality is deeply rooted in digital culture. It is a historical misunderstanding, however, to think that analog culture ignores transmediality. As clearly shown by Dominique Kalifa (2001) and many others, transmediality is a cultural and economic phenomenon that comes to the fore as soon as cultural production enters the field of capitalist mass production (cultural industries need a return on investment, and transmedialization is one of the easiest ways to achieve this goal). Granted, digital culture clearly encourages and fosters transmediality, yet it did not invent it. ${ }^{1}$

Second, it should also be stressed that similar arguments have been made about the «natural» link between fantastic and transmediality. In current scholarship, this link has become common knowledge, as shown for instance in the recent book by Colin Harvey, Fantastic Transmedia (2015). Nevertheless, the emphasis in this kind of works is always more on issues of transmediality than on fantastic issues, and the link with interactivity is also something that remains understudied. In other words: it is true that the fantastic is often transmedialized, but this does not mean that transmediality is fantastic per se.

Third, it would be a mistake to think that transmedialization (the process of shifting from one medium to another) and transmediality (the result of such a shift) are homogeneous operations or situations. Both terms cover a wide range of very different operations, which it is unfortunately not possible to present here in detail (see also Sánchez-Mesa, 2019 and Thon, 2016). What matters most in the context of this article is the fact that transmediality is not something that always «works»: successes and failures are both possible, depending on the specific ways the adapting medium is being used and the decisions taken in the process of adaptation. Take for instance the classic example of the movie adaptation of a fantastic source text (novel, comic or videogame) and check how there are times where the transmedialization

1 It is worth stressing as well that digital culture and the cultural-industrial environment bond to it both needs and creates in order to «perform» a certain idea of culture. It also has a profoundly ambivalent impact on transmediality. It is centrifugal, since it strongly encourages various types of transmedial remediations. But it is also highly centripetal, since it tends to control by all kind of legal means the users' appropriation and "savage», that is unauthorized reuse of its copyrighted and trademarked material. The discussion of this question exceeds, however, the scope of this article. 
seems to «enhance» the fantastic effect of the original, as it could be the case of some Stephen King's novels, like The Green Mile (1996) adapted by Frank Darabont (1999), or The Outsider (2018) adapted by Richard Pride and directed by Richard Bateman for a miniseries at HBO (2020). On the contrary, there are also times when the opposite seems to occur, as it happens with Zack Snyder version (2009) of the cult comic series Watchmen (Moore \& Gibbons, 1986-87) or the film adaptation of the classic of the survival horror genre in videogames, Silent Hill (Konami, 1999) by Cristoph Gans (2006). Due to the technical limitations of the then still rather «primitive» stop-motion technique, the first adaptation of Conan Doyle's The Lost World (Doyle, 1912) by Harry O. Hoyt was definitely less convincing than later filmic versions of the same work (Hoyt, 1925).

All these observations suggest that transmedializing a fantastic work is both possible and problematic. The problem is that each transformation has always something to win or something to lose. In other words: the transmedialization of a fantastic work produces a work whose fantastic aspects are either increased or diminished, but never in a uniform way. One cannot win without also losing something, one cannot lose without also winning something, as seen for instance in the comparison between film and novel. A film seems more immersive, but one can be hindered by the reactions of other spectators; a movie seems less immersive, but one will more rarely be bothered by the reactions of other readers. All transmedial changes inevitably affect the intermedial structure of the new formats, and these changes have their consequences for the way in which the fantastic is experienced.

As far as interactivity, our third key term, is concerned, this notion is situated at the crossroads of two fundamental mechanisms of today's culture: participatory culture, on the one hand, and convergence culture, on the other hand. Yet there is no consensus on what interactivity actually means. There is even less consensus on how to evaluate its importance. Most scholars tend to underline the diversity and multilayered character of the phenomenon, which cannot be reduced to the more or less mechanical performing of certain actions by end-users in front of a computer interface (Aarseth, 2004 and Ryan, 1991). By far, the most sophisticated overview and taxonomy has been elaborated by Jean-Pierre Fourmentraux, who distinguishes between the following types (we summarize here from Fourmentraux, 2005: 90-107): ${ }^{2}$

2 By the way, similar ways of thinking on other key notions such as «writing» have been in the center of other recent scholarship, see Leibovici (2020). 
Exploratory interaction: based on the principle of navigation and aiming at experiencing the work.

Contributing interaction: based on the principle of execution of commands and aiming at an activation of the application.

Alterating interaction: based on the possibility of changing the work, yet always within the rules and procedures as programmed by the work itself, and aiming at either making transformations or adding new materials.

Alteracting interaction: based on the principle of communication between all those who collaborate in the making of the work, and foregrounding alteraction, that is the reaction in real time to the action of other agents.

Even more controversial is the evaluation of the importance of interactivity, which has frequently been dismissed as a pure myth, if not a crude illusion (for a recent overview in the field of digital narrative, or see Punday, 2019: 78-79). This critical attitude may be explained by the excessive expectations that were raised in the initial stage of modern digital culture (in the, 1980s and 1990s, with the emergence of the personal computer and the first efforts to link the shift from analog to digital with the most radical claims of predigital critical theory, as in Landow, 1992). It is now time to adopt a more modest, but perhaps also more efficient take on the issue of interactivity.

Crucial in this regard remains, however, the relationship between interactivity and medium theory (and thus also transmediality). As convincingly demonstrated by Julien Baudry (2018) in his study on the history of digital comics in France, our use of interactivity cannot be separated from the way we envisage certain media. In the case of comics, the many failed attempts to introduce «strong» forms of interactivity, for instance by using comics as a laboratory in the development of cultural content for the (now deceased) CDI technology, clearly show that users are reluctant to actually make use of interactive elements in transmedialized comics if these elements prove incompatible with the general ideas on a given medium. Interactive comics may have been technically perfect and cognitively stimulating, but they were rejected by the readers who did not succeed in relating them to their current views of what the comics medium was standing for (and as medium theorists such as Stanley Cavell (1979) have rightfully stressed, ideas on what a medium «is» are actually quite constraining), for instance at the level of page layout (most CDI comics did not respect the traditional «grid», which made that they did not qualify as comics for comics readers), the absence of sound (comics readers are always disappointed when they discover how characters «speak», for instance in animated transmedializations), and the importance of the material 
host medium (the graphic novel is a medium that is infamously reluctant to the digital turn). In other words: the fantastic effect some forms of interactivity are aiming at cannot work, that is «be successful», if they cannot be integrated in specific traditions and uses.

By way of example: J. K. Raymond Millet / René Barjavel and Wim Delvoye

It is about time now to present some detailed examples of the connections between the fantastic, transmediality and interactivity. We will do so by addressing two works that help illustrate the broad range and scope of media and mechanisms under scrutiny. In either case, however, the essential aim of our analysis is to underscore the change, more particularly the increase, of the fantastic effect as it results from the ways in which users interact with transmedialized objects. But before presenting our case studies, it will be helpful to remind us about the need to establish different levels or kinds of interactivity, following Marie-Laure Ryan's distinction between a «literal» and a «figurative» concept of interactivity, being the former the classic collaboration of the reader/viewer in the making of meaning out of the text signs and the latter the «real» agency of the reader to control, or at least participate, in the process of textual happening or performance. Espen Aarseth coined a more precise and nuanced concept which embeds this kind of material interactivity: «cybertextuality» (Aarseth, 1997). Within that second dimension of interactivity (the «literal»), Ryan detaches a «weak» from a «strong» interactivity, where the first reduces the reader/user agency to a set of simple choices predefined by the (hyper)text while the second conveys a participation in the «physical» production or at least configuration of the text (Ryan, 2001: 35). ${ }^{3}$

Our first example is Télévision, oeil de demain, a 1947 short movie directed by J. K. Raymond Millet (Millet, 1947) and based on ideas borrowed from a book by SF author René Barjavel, Le Cinéma total (Barjavel, 1944). This work is a (pseudo-)reportage on the projected evolution of a certain medium device, whose future and still totally unreal developments are presented as already implemented in daily life. The device in question is television, a medium that had not yet entered the private homes at that time, and the projected evolution was that of the transformation of television into what we would call today a

3 In the second edition of her book, Ryan enriches this taxonomy on the double axe of «internal» vs. «external» interactivity and «exploratory» vs. «ontological» ones (2015: 162), but for our purpose in this article we restrict our reading to her early distinction. 
smartphone (even if more revolutionary and unexpected changes are briefly hinted at). The four minutes documentary of Millet shows the fantastic effects of the new invention, which blurs the boundaries between real life and life on screen, with for instance drivers watching a news report on car accidents on the micro-television screen in their car and thus provoking new accidents, or the replacement of old school politicians by a new type of glossy "politicians», whose major quality is to be good looking and soft-voiced, capable of seducing the audience regardless of any serious content (by the way, this seduction is highly gendered: women in French only obtained their voting rights in 1944 [!] and it should not come as a surprise that Millet's strongly gender-stereotyped movie insists on the intellectual weakness of the female voter).

What interests us most in this work is that the fantastic effect of the blurring of boundaries is presented as the combined result of transmedialization and interactivity. The new and miniaturized engine allows the user to have a tactile interaction with the screen and, in a second stage, with the images on the screen: the car accident on television generates a real car crash, the young girl watching the new look politician does not only point at the screen, she also touches her mother who is sitting next to her in a gesture that metaphorically represents the desire to touch her hero on the screen. One might say that the fantastic effect produced by the mix of transmediality and interactivity is that of a generalized but always uncanny metalepsis (Genette, 2004, Kukkonen and Klimek, 2011).

The second example points in a totally different direction, not only because it addresses a different type of medium change, but also because it seems to involve, at least at first sight, a reduced or figurative form of interactivity. It appears however that, as far as the fantastic effects are concerned, similar mechanisms take place, which are as powerful as the ones examined in Télévision, oeil de demain.

The work in question is «untitled (CS_DUST 07)» by Belgian artist Wim Delvoye (Delvoye, 2018), probably best known for his controversial and often censored tattooed pigs (an equally blatant case of transmediality with strange interactivity aspects, for we do not touch pigs as we touch human skins). Delvoye's work proposes a curious «translation» of an image of a war video game: instead of just printing a screenshot (like the images we flip through in a magazine, for instance) or to emulate the digital game in a real life action movie (like in Gus Van Sant's Elephant [Van Sant, 2003], his reinterpretation of the Columbine High School massacre where the camera systematically occupies the position of the player in a video shooter game), Delvoye converts it into a 
marble bas-relief (having the size of a large video screen: $64 \times 38,5 \times 10 \mathrm{~cm}$ ). The result is stunning, and the spectator of this sculpture is confronted with a representation that is, in spite of its fixed monumentality, utterly fantastic. Here, the blurring of the boundaries does not involve the clash of fiction and reality, as in the French documentary, but the clash of different types of fiction: the adapted video image is banal and highly commercial, as well as violent and fast-moving; the marble bas-relief connotes tradition and high culture, while also being the epitome of stillness and extratemporality. For literary minded spectators, it is difficult not to think of Keats's «Ode on a Grecian Urn» (Keats 1819). Delvoye's marble piece is a kind of paradoxical tableau vivant, but one that is meant to be performed forever. And here as well, interactivity is fully present, even if not in a cybertextual mode, to enhance the effects of the transmedial changes. As argued by Fourmentraux, interactivity cannot be reduced to mere physical contact, pushing buttons or clicking through links. In Delvoye's sculpture, it is our gaze itself that becomes haptic, that touches the sculpted work instead of just looking at it. By doing so, our gaze directly interacts with the sculpture, whose intriguing status of transmedialized item forces us to rethink and eventually transform our classic ways of looking.

A USE(R)-BASED APPROACH OF MEANING

The twin examples of Millet and Delvoye can now be the starting point of some more general hypotheses concerning the links between the three key notions of this essay.

The basic claim of our way of addressing the mutual links between fantastic, transmediality and interactivity, is anti-essentialist. Meaning is use, as Wittgenstein famously argued. In this context, this comes down to asking how interactivity plays a role in the interpretation of transmedial operations of fantastic works and how it either increases or diminishes the fantastic effect on reader and/ or viewer (there exists of course also a fantastic that is induced by other senses, but our examples will be mainly verbal and visual). This is a very different question from asking how fantastic works happen to be transmedialized and how interactivity is one of the features of such a transmedialization. The latter question is production-oriented and takes the fantastic effect as a given. The former question is more reception-oriented and considers the fantastic as either a successful or a failed consequence of the twofold mechanism of transmediality and interactivity. Moreover, this question accepts that the 
user does not necessarily understand what is, technically speaking, going on in the technology of both intermedial and interactive mechanisms. In many cases, users do not understand the specific operations that produce transmediality (the special effects of digital cinema, for instance) and allow for interactivity (the logarithms that control our dialogue with the computer interface, for example). Users notice the absence or presence of interactive devices in transmedial operations, without always realizing «how things work» — certainly in the case of digital applications-, but this limited knowledge does not prevent them from actually interacting and having a certain experience of the difference between interactive and noninteractive transmedializations.

This aspect of «non-understanding», which enables users to interpret the role of interactivity without always realizing how it is being produced, is vital in a user-based approach. First of all, because it would be somewhat contradictory to argue that in matters of interactivity, which cannot be separated from the larger context of participatory culture, the role of the specialist, generally the engineer or the technically trained scholar, is to be given more weight than that of the amateur, that is the actual user. As Lisa Gitelman puts it: «A computer engineer can explain how digital files really are created and saved, but I would insist that the vernacular experience of this creatability and savability makes at least as much difference to the ongoing social definition (that is, the uses) of new, digital media» (Gitelman, 2008: 20).

Second, because the technological opaque should not be dismissed as a user's error or failure, but as a decisive feature of new forms of art and media, whose very opacity foregrounds new forms of experience, including in the realm of the fantastic. As defended by James $H$. Hodge in his discussion of the videogame Cookie Clicker (Orteil, 2013), where the fantastic effect results from the tension between active and passive participation in a game that rapidly confronts the gamer with her own inutility:

Things seem to be happening, but I'm less and less a part of the action. Cookie Clicker is a game about computing. Like a Lovecraftian adding machine counting into oblivion, Cookie Clicker offers a wry, weird rebuke to the idea of interactivity, often thought to be central to digital aesthetics. Far from expanding human experience through play or cybernetic possibilities, the game makes plain how little computers need people. By doing so, Cookie Clicker articulates what it means to live in relation to digital media as the infrastructure of experience. It gives the lie to the myth of any one-to-one or happy, symmetrical relation between individual personhood and the operation of technology (a myth fostered conspicuously by the imagination of computers as «personal computers»). 
Cookie Clicker explores instead what it means to live in radically asymmetrical relation to the opacity of digital media and their operation over and above human experience (Hodge, 2019: 28-30).

In order to analyze how interactive effects of transmedial fantastic work in a user-based perspective, many different methods are at our disposal: surveys, participatory observation, literature research. In what follows, we will go for a qualitative research that explores some theoretical hypotheses, which we will briefly illustrate with some examples and case studies. Although we will not develop this method in detail, it may be useful to specify that our implicit yet overall framework is that of tensive semiotics (Fontanille, 2008; for a brief presentation, see Hébert, 2019: 56-65). We will thus consider the fantastic, that is the fantastic effect, as the sign as experienced by the user, more precisely by the user's body and embodied mind, whose experience is determined by the junction or tension of two determining forces, «intensity» and «extent», the former referring to the affective perception or feeling (intensity is a state of mind: do we consider a sign as more or less fantastic?), the latter referring to the part of the world that is involved in our understanding of the sign (extent is a state of affairs: how does the sign help us grasp the world, more specifically the world as fantastic?). The «meaning» of a sign is therefore the result of the tension between intensity and extent, but this tension is never limited to just one moment in time: intensity and extent may change over time, and these changes have their impact on the experience of the sign; for the fantastic effect is an unstable one, it can intensify or on the contrary fade away.

Since we are discussing the links between interactivity and transmediality, this temporal or dynamic dimension is not a detail. The signs we are analyzing are moving from one medium to another and these moves are never a zero-sum game. There is always something that is won or that is lost, for instance in terms of the fantastic effect. Let us take here a very simple and classic example, that of the fantastic short story by Borges «El libro de arena» («The Book of Sand»), the opening story of the eponymous collection (Borges, 1975). At the center of this story is a special «Holy Writ», printed in Bombay, which appears to be a book with neither a beginning nor an end. Indeed, when the narrator opens this book, he is startled to discover that the book, which is written in an unknown language and occasionally punctuated by illustrations, is in fact infinite: if one turns the pages, more pages seem to grow out of the front and back covers. Each reading is different, it is impossible to read the same page twice. Since Borges was already blind when writing «The Book of Sand», 
we know that he first made a mental composition of the tale, before dictating it in order to have a print version. This simple transmedialization, from orality to writing, is dramatically efficient, for it brings the audience much closer to the fantastic object: when just listening to the story, provided it would be read aloud, for instance on the radio, we can only «imagine» the fantastic effect, but while reading it in a book that we hold in our hands, we can actually «check» what Borges is insinuating, namely that all texts are infinite, since no reader can make the same reading twice.

In this article, we will present a double hypothesis. One that has primarily to do with the axis of intensity, which we will address with the help of the binary opposition surprise / suspense (in the traditional sense elaborated by Hitchcock in his conversations with Truffaut, see Truffaut, 1985: 58-59), for these terms concentrate on one of the basic mechanisms of the fantastic, namely the shock effect. And one that has principally to do with the axis of extent, which we will address here with the help of the cognitive categories of understanding and focalization (each of them related with the notion of «dispatching of information»). Given the importance of time, for the fantastic effect is never a given but something that unfolds in time, we will in both cases pay careful attention to narrative aspects. However, since a semiotic analysis also has to consider pragmatic and contextual features - if not, it will fall prey to the tenets and limitations of some «universal grammar»-, we will always emphasize the open character of our hypotheses and end with some remarks on contextualization.

\section{HYPOTHESIS 1: ONCE AGAIN ON SURPRISE VERSUS SUSPENSE}

Shock effects are not rare in fantastic literature and cinema, and the idea of a sudden revelation looms large in many productions. The emotional power of these effects makes it a good candidate for a discussion on the «intensity» aspect of the relationship between interactivity and the fantastic. However, it would be absurd to put between brackets the other dimension, that of the «extent». Indeed, in the scholarly reflection on the shock effect, the distinction between «surprise» and «suspense», as elaborated for the larger audience by Alfred Hitchcock in his famous conversations with François Truffaut, the importance of the cognitive dimension becomes very clear, as Hitchcock insists upon the difference between both mechanisms in terms of knowing audiences versus unknowing audiences: the shock effect of the surprise depends on the fact that the audience does not have the some knowledge of 
the narrator / director, ${ }^{4}$ whereas suspense is a way of telling that supposes a shared knowledge between narrator/director and audience. Yet Hitchcock also strongly underlines the role of time: surprise can only work when it happens instantaneously, while surprise is something that has to be built up.

Surprise, as well as suspense, are in principle relatively easy to transmedialize. Yet it would be a mistake to think that the same applies to the inclusion of interactive mechanisms during this process, and here time plays a decisive role. One may have the impression - and this is the first of the two general hypotheses we would like to put to the test - that surprise effects are broken, or at least weakened, if the user can interactively "play» with time, thus reducing the «sudden impact» of surprise effects. Take for instance David Lynch's Blue Velvet (1986). In a key scene, the protagonist of the movie, Jeffrey Beaumont, a college student, attends from the closet where he is hidden a «fantastic» scene between the mysterious lounge singer, Dorothy Vallens, and a strange man, actually a gangster, Frank Booth, who beats her and subjects her to a series of strange sexual acts during which he appears to Jeffrey as a kind of werewolf. This «surprise» (amplified by a general atmosphere of «suspense» that drives the whole movie) would be seriously damaged if the spectator, instead of being immersed - that is: forced into immersion - by the theatrical environment and the apparatus of traditional cinema, would have the possibility, for instance when watching the film on DVD or online, to slow down or to accelerate, if no to stop time, to rewind, to repeatedly view the same image, or even to skip it, etc. Such a liberty would probably severely damage the shock effect and thus the fantastic impact of the image of the man turning into a wild animal. Similar consequences can be suggested in the case of more sophisticated forms of interactivity, such as for instance the sliding the mouse over the screen, a technique often used to produce visual and other changes meant to produce fantastic effects. The very fact that users can manipulate themselves the use of the mouse (for instance by... not using it, or waiting to use it before actually doing it, only using it after having imagined which new form will appear, etc.) may have a great impact on the fantastic effect, certainly in the case of surprise structures.

Conversely, the building up of suspense can be strongly reinforced by the interactive manipulation of the transmedial mechanism, as shown for instance by Michelangelo Antonioni's Blow-Up (1966). In this movie, the main character, fashion photographer Jeffrey, takes by accident photos of two lovers

4 The debate on the analogies and differences between author, narrator and implied narrator is not an issue during the conversations Hitchcock-Truffaut and there are no special reasons to open this debate here. 
in a park. Later on (we leave here aside the actual storyline of the film) he makes many enlargements of the photos, which progressively reveal many «unseen» elements, thus producing a fantastic atmosphere where things are no longer what they look like. Here as well, interactivity is crucial: the more the photographer manipulates the images, the more fantastic the world becomes.

Similar mechanisms occur, yet here at the level of the sound-track, in Francis Ford Coppola's The Conversation (1974), where the protagonist, Harry Caul, a surveillance expert specialized in recording secret conversations in technically difficult circumstances, finds himself trapped in a special case where the «conversation» he has managed to separate from all kind of background noises proves to hear crystal-clear words, but a very obscure meaning. Moreover, the rest of the story reveals that he himself is being surveilled against his will. Despite his exceptional technological competences, his efforts to discover the listening devices that spy on him remain fruitless, a situation that eventually will drive him mad. The analogy with Blow-Up is obvious: the more Harry Caul manipulates the sounds he is working with, the more the plot thickens and the more «everything» becomes suspect in a generalized paranoia.

If we grasp one case which belongs to the domain of videogames, where a properly cybertextual (hard) interactivity is expected, Nieves Rosendo displays a thorough analysis of Alan Wake (Remedy Ent., 2010) from a different perspective, but also chasing the particularities of the intermedial references imported from the classical modes of the fantastic (literature and cinema). Rosendo underlines the relevance of immersion as we play the role of the main character, the horror novel writer Alan Wake. As the player discovers and gathers pages of his diary, she has an extended experience of time through interactivity and she does so more on the side of suspense than of surprise, as those pages function as anticipation of actions/events that the player will embody. Rosendo quotes Kirkland (2009) in relation to the presence of the typewriter machine in Resident Evil (Capcom) to stress that remediation of analog mass media in survival horror videogames plays a major role in Alan Wake, in this case television, e.g., the character watching himself in a live tv interview or the shooting style and aesthetic of the game scenarios and navigating possibilities, inspired in classic tv series such as The Twilight Zone (first series: Serling, 19591964) or Twin Peaks (Lynch, 1990-1991) (Rosendo, 2015, 79).

In other words, there seems to be a relationship between the decrease of the fantastic effect and the fact that the transmedialization allows or not for strong interactivity in the case of a surprise/suspense based fantastic. This relationship can be experienced in two ways. On the one hand, users can ex- 
perience it directly, when for instance playing a video game or reading a book, for both the screen and the printed volume have to be put in motion and manipulated by their users. On the other hand, they can also do so indirectly, via the vicarious experience of a fictional character performing an action on screen or on the page, an action that the reader or spectator can then cognitively as well as bodily repeat or emulate. Certainly in the latter case, where one seems to have to «undergo» the work rather than having the possibility to influence the way in which it is read / seen, there is a very strict temporality that strengthens immersion and thus the fantastic, both in the case of surprise and of suspense. But if interactivity helps manipulate the temporal distance between stimulus (of the work) and reaction (of the audience), the transmedialization will have a different impact on surprise effects (which may be faded) and suspense effects (which may be supported).

In all cases, however, caution is needed. The above presented hypothesis as well as the examples that illustrate it do of course not suffice to make very hard claims. Even if it is not possible to argue yet that the interactive manipulation of time in certain forms of transmedial surprise/surprise mechanisms will lead to this or that effect, it seems plausible to admit that interactivity cannot be seriously studied without a careful examination of time (interactivity is «time-based»), on the one hand, and that it would be an error to think that interactivity has some natural or organic link with the fantastic (depending on the situation, interactivity will either contribute to the fantastic effect or function as a threshold).

HYPOTHESIS 2: ON RESTRICTION OF INFORMATION AS A NARRATIVE ISSUE

The second hypothesis we would like to present expands on the first one, while tipping it over to the axis of «extent», that is of knowledge and the amount of information we grasp via the fantastic sign. Knowledge or, more precisely, the lack thereof or the hesitation between knowing and not-knowing are essential but very complex and multifaceted aspects of the fantastic. The example of magic illustrates that duplicity very well: if we know how the trick works, we will no longer be impressed, unless we start watching more closely all the work that has to be done in order to make the trick successful, and that sharpened attention may engender a second-level increase of the fantastic effect (the fact that we see the strings in a puppet show does not necessarily reduce the possible impact of the fantastic, if any, in the show). In Revoir Paris (Schuiten and 
Peeters, 2014), a transmedialization and reinterpretation in comics format of an exhibition of visual utopias of Paris at the «Cité de l'architecture et du patrimoine», materializes in its fiction the immersive effect of watching utopian drawings of Paris as it may look like in the 22nd century: the protagonist of the book, who travels from an unknown universe to planet Earth dreams over 19th century books, taking a special drug to try to anticipate her arrival in the city where she will both dwell as a ghost and act as a real-life inhabitant - at least as long as the drug works. This fictional materialization of what it means to be «immersed» in a story world does not prevent the actual «user», be it the visitor of the show or the reader of the graphic novel, to empathize with the character and to feel immersed in her turn in the fantastic world of utopian Paris.

But what happens when transmediality and interactivity meet? Here as well, we would like to stress the importance of time and link the difference between knowing and unknowing with two types of reading narratives. As clearly established by Raphaël Baroni (2011), among others, a story can be read in two major ways: either retrospectively (after having read the story, we try to see how it is made) or on the spot, while it unfolds (we imagine the way the story is built while moving through the work, sentence after sentence, shot after shot, etc.: the focus on surprise/suspense for instance is clearly depending on this kind of reading). Both readings are necessary and complementary, but their differences matter for the study of interactivity in transmedialized fantastic works. It seems logical to suppose that the fantastic effects will be dramatically modified by the availability of interactive tools and devices, while the impact of interactive aspects will be less relevant in the case of a completely retrospective reading of the story, where we are no longer experiencing interactivity on the spot, in all its immediately working effects, but where these effects have already been taken on board for the global appreciation of the fantastic. This is for instance the case in certain forms of fan fiction of SF works such as Star Trek (2020) or Star Wars (2020), which may include many interactive tools and techniques - one may think here of the possibility to add variations or to start a discussion with other fans on certain developments-, but in general this type of interactivity always takes place on the background of already known stories (and in this case, even of sharply circumscribed story worlds or universes).

Obviously, much caution is here needed as well, and much more case studies and other examples should be studied before making hard claims. Yet the special link of interactivity and temporal structures cannot be questioned and all discussions on the transmedialization of fantastic works will miss a vital feature if they do not scrutinize this specific aspect of use in time. 
As the previous paragraphs have made clear, our first methodological proposals do not have the pretention to build a new Grand Theory. The major objective of this essay was to explore the links between transmediality and interactivity in the field of fantastic texts, images, and worlds, not just at the level of the works themselves but seen from the standpoint of the user. Such an approach obliges to take into account contextual and cultural elements, as we have tried to show through the twin examples of the Millet documentary and the Delvoye sculpture.

We have tried to suggest that it does not suffice to merely examine the very materiality of the context in which users are interactive: their tools may be different (and the same applies to the knowledge of their tools). Taking as our theoretical as well as methodological starting point the framework of tensive semiotics, which helps study the qualitative as well as quantitative dimensions of user's experience, we have elaborated a double hypothesis covering each of these dimensions: the former aspect («intensity») has been studied via a revision of the tension between suspense and surprise; the latter one («extensivity») has been approached via a rereading of focalization mechanisms.

Further research will of course have to complement our theoretical framework with the help of empirical evidence. In this regard, it will definitely prove useful to link the framework of tensive semiotics with the more empirically based semio-pragmatic view as elaborated by Roger Odin (2000), who describes how users actually experience certain intended forms and how one can explain the possible gap between intended effect and final result (and this matches with our concern about the degree of success or failure of the fantastic as produced with the help of transmedial and interactive forms and techniques).

\section{BIBLIOGRAPHY}

AARSETH, Espen (1997): Cybertext. Perspectives on Ergodic Literature, John Hopkins University Press, Baltimore \& London.

— (2004): «Genre Trouble: Narrativism and the Art of Simulation», in Noah Wardrip-Fruin and Pat Harrigan (eds), First Person: New Media as Story, Performance, and Game, MIT Press, Cambridge, MA, pp. 45-55.

Antonioni, Michelangelo (dir.) (1966): Blow-Up, Bridge Films, United Kingdom / Italy. 
BAETENS, Jan \& Domingo SÁNCHEZ-MesA (2019): «La literatura en expansión. Intermedialidad y transmedialidad en el cruce entre la Literatura Comparada, los Estudios Culturales y los New Media Studies», Tropelías, n 27, pp. 6-27, available in: <https:/ / papiro.unizar.es/ojs/index.php/tropelias/article/view/1536> [accessed: 12/08/2020].

- (2019): «El giro transmedial en la investigación en nuevos medios digitales de comunicación: el concepto de demediación», in Francisco Sierra Caballero and Jordi Alberich Pascual (eds.), Epistemología de la comunicación, Editorial de la UGR, Granada, pp. 163-175.

Barjavel, René (1944): Le Cinéma total, Denoël, Paris.

BARONI, Raphaël (2011): «Le récit dans l'image: séquence, intrigue et configuration», Image and Narrative, vol. 12, no 1, pp. 272-294, available in: <http:/ / www.imageandnarrative.be/index.php/imagenarrative/article/view/136/107> [accessed: $12 / 08 / 2020]$.

Bateman, Jason (dir.) (2020): The Outsider (TV series), HBO, United States.

BAUdry, Julien (2018): Cases-Pixels. Une histoire de la BD numérique en France, Presses Universitaires François-Rabelais, Tours.

Borges, Jorge Luis (1975): El libro de arena, Emecé, Buenos Aires.

Cavell, Stanley (1979): The World Viewed. Reflections on the Ontology of Film, Enlarged Edition, Harvard University Press, Cambridge, MA

Coppola, Francis Ford (dir.) (1974): The Conversation, American Zoetrope/ Paramount.

Delvoye, Wim (2018): CS_DUST 07, Private collection.

Doyle, Arthur Conan (1912): The Lost World, Hodder \& Stoughton, London.

Fontanille, Jacques (2008): Pratiques sémiotiques, PUF, Paris.

Fourmentraux, Jean-Paul (2005): Art et Internet. Les nouvelles figures de la création, CNRS éditions, Paris.

GANs, Cristoph (dir.) (2006): Silent Hill, Silent Hill DCP Inc. / Davis-Films, Canada / France. Genette, Gérard (2004): Métalepse. De la figure à la fiction, Seuil, Paris.

HоYт, Harry O. (dir.) (1925): The Lost World, First National Pictures, United States.

Gitelman, Lisa (2008 [2006]): Always Already New; Media, History, and the Data of Culture, MIT Press, Cambridge, MA.

Grivel, Charles (1992): Fantastique-Fiction, PUF, Paris.

Harvey, Colin (2015): Fantastic Transmedia. Play and Memory Across Science Fiction and Fantasy Storyworlds, Palgrave Macmillan, Hampshire.

HÉBERT, Louis (2019): An Introduction to Applied Semiotics. Tools for Texts and Images, available in: <http:/ / www.signosemio.com/documents/Louis-Hebert-Tools-forTexts-and-Images.pdf $>$ [accessed: 12/08/2020].

Hodge, James J. (2019): Sensations of History, University Press of Minnesota, Minneapolis. Jenkins, Henry (2006): Convergence Culture. Where Old Media and New Media Collide, New York University Press, New York.

KaLIFA, Dominique (2001): La Culture de masse en France. 1860-1930, La Découverte, Paris. KEATS, John (1819): «Ode on a Grecian Urn», first published in Annals of the Fine Arts, available in: <https://www.poetryfoundation.org/poems/44477/ode-on-agrecian-urn $>$ [accessed: 12/08/2020]. 
KING, Stephen (1996): The Green Mile, New American Library.

- (2018): The Outsider, Charles Scribner's Sons, New York.

KukKonen, Karin \& Sonja KlimeK (eds.) (2011): Metalepsis in Popular Culture, De Gruyter, Berlin.

Landow, George (1992): Hypertext: The Convergence of Contemporary Critical Theory and Technology, Johns Hopkins University Press, Baltimore.

LeIBOvici, Franck (2020): Des opérations d'écriture qui ne disent pas leur nom, Questions théoriques, Paris.

Letourneux, Matthieu \& Jacques Migozzi (2018): «Hommage à Charles Grivel», special issue of Belphégor, vol. 16, nº 1, available in: <https: / / journals.openedition.org/ belphegor/1056>

Lynch, David (dir.) (1986): Blue Velvet, De Laurentiis Entertainment Group, United States.

— (dir.) (1990-1991): Twin Peaks, ABC, United States.

Millet, J. K. Raymond (1947): Télévision, oeil de demain, available in: <http:/ / www.ina. $\mathrm{fr} /$ video/I10257139> [accessed: 12/08/2020].

Mitchell, W. J. T. (2005): «There Are No Visual Media», Journal of Visual Culture, vol. 4, no 2, pp. 257-266, available in: <https: / / journals.sagepub.com/ doi / 10.1177/ 1470412905054673> [accessed: 12/08/2020].

Moore, Alan \& Dave GibBons (1986-87) Watchmen, DC Comics, United States.

ODIN, Roger (2000): De la fiction, De Boeck, Bruxelles.

ORTEIL, aka Julien Thiennot (2013): Cookie clicker, Dashnet, available in: <https:/ / orteil. dashnet.org/ cookieclicker/>

Punday, Daniel (2019): Playing at Narratology. Digital Media as Narrative Theory, Ohio State University Press, Columbus, $\mathrm{OH}$.

Remedy EnT. (2011): Alan Wake, available in: <https://www.remedygames.com/games/alan-wake/> [accessed: 12/08/2020].

RoAs, David (2001): «La amenaza de lo fantástico», in David Roas (ed.), Teorías de lo fantástico, Arco Libros, Madrid, pp. 7-49.

- (2011): Tras los límites de lo real. Una definición de lo fantástico, Páginas de Espuma, Madrid.

Rosendo, Nieves (2015): «Lo fantástico en Alan Wake: remediación, intermedialidad y transmedialidad», Brumal. Revista de Investigación sobre lo Fantástico; vol. 3, n 1, pp. 73-93, available in: <https:/ / doi.org/10.5565/rev/brumal.181> [accessed: 12/08/2020].

Ryan, Marie-Laure (1991): Possible Worlds, Artificial Intelligence, and Narrative Theory, Indiana University Press, Bloomington, IN.

- (2001): Narrative as Virtual Reality, John Hopkins Univ. Press, Baltimore \& Maryland.

SÁncheZ-Mesa, Domingo (ed.) (2019): Transmedial narratives, Gedisa, Barcelona.

Schuiten, François \& Benoît Peeters (2014): Revoir Paris, Casterman, Paris.

SERLING, Rod (dir.) (1959-1964): The Twilight Zone, CBS, United States.

SNYDER, Zack (dir.) (2009): Watchmen. Warner Bros, United States.

STAR TREK (2020): The Official Site, available in: <https:/ / intl.startrek.com/> [accessed: $12 / 08 / 2020]$. 
STAR WARS (2020): The Official Site, available in: < https:/ / www.starwars.com/> [accessed: $12 / 08 / 2020]$.

THON, Jan-Noël (2016): Transmedial Narratology and Contemporary Media Culture, University of Nebraska Press, Lincoln.

Todorov, Tzvetan (1970): Introduction à la littérature fantastique, Seuil, Paris.

Toyama, Keiichiro (1999): Silent Hill, Konami, Japan.

TrufFaut, François (1985 [1966]): Hitchcock/Truffaut. Revised Edition, Simon \& Schuster, New York.

VAN SANT, Gus (dir.) (2003): Elephant, Meno Film Company, United States. 